\title{
Medea, Melodrama and the Limitations of Perception
}

\author{
Michael Beckerman
}

Medea is not a particularly pleasant tragic heroine, and one might even argue that something like melodrama was necessary to capture her jagged edges: neither this nor that, she is a creature who never allows us to put the whole thing behind us. Medea as a prototypical early melodrama is a symbolic goad and a prod, and the impossibility of assembling her completely has led me to the following meditations on stage melodrama, something, I will suggest, equally difficult to fully assimilate.

I.

It has long been noted, often with some irony, that while melodrama never came close to rivalling opera, and, in fact, was a somewhat marginal musical form, it has become a staple of two of the most popular media in the history of the planet, that is, film and television. How could it be that stage melodrama, a genre so well-intentioned, and one that makes so much sense, is at best a novelty item, apart from in a few places in the world? After looking briefly at the rationale for stage melodrama, I shall also look at its limitations and why, at the same time, the same basic issues of cognition resulted in the success of film and the failure of staged melodrama.

First the good news. As Mozart and many others have noted, stage melodrama is a genre with seemingly endless potential. First and foremost, it addresses an issue that has been around from the moment text and tone were combined. In thinking about this, I always remember Algernon's confounding line from Wilde's The Importance of Being Earnest: "Of course the music is a great difficulty. You see, if one plays good music, people don't listen, and if one plays bad music people don't talk." What interrupts what? Once a sonorous ideal was associated with musical sound a text posed vexing problems. Either one elevates the abstract patterning associated with music, and fits the text in somehow, or one preaches fidelity to the text as declaimed, and thus distorts potential musical patterns. Battles have raged for centuries, and solutions to this are posed in the various kinds of recitative that have evolved, and are posed and reposed in Janáček's speech 
melody theories, hip hop and the blues, in Bob Dylan's "Like a Rolling Stone", and in the declamatory patterns of contemporary opera.

What melodrama offered was an entirely new solution. Not only could (and should) one abandon the idea of altering music and text to suit each other, they could exist in their pure forms side by side as equals. Speech could be speech, as dramatically powerful as one could imagine it, and music, not having to change itself to fit the pattern of words, was free to be itself, also at its most powerful.

But there was to be another, possibly even greater benefit. No longer would music drama be at the mercy of singers, who at any moment could rebel, turning the entire proceedings into a matter of vocal virtuousity, and stupefyingly bad acting. Real actors, trained to move upon the stage, trained to project their voices and gestures with enormous power, would now be in control. Great theatre supported by great music, creating effects heretofore impossible: a never-dreamed-of power, orchestra and actor together.

We know that this did not work out as planned. There is no "Metropolitan Melodrama House" where we hear the great stage melodramas of Mozart, Verdi and Smetana, and not even in the Czech Republic are we likely to encounter stage melodrama very often. What went wrong, why, and is there anything to be done about it?

II.

There were two structural problems from the outset that dogged the genre, and one fundamental institutional one. First, because of melodrama's genuine success in capturing the rhythms of contemporary staging, it is a genre almost impossible to update. In other words, the pace of the piece is predetermined. And this creates a second fundamental problem, not easy to overcome. For the great advantage of melodrama was to allow actors on the stage to ply their craft, use their voices and their bodies to create effects that at the very least would rival those of the singers. But melodrama ends up doing precisely the opposite. By either forcing the actor to speak along with the music, or surrounding actorly speeches with musical punctuations, the actor's freedom is considerably diminished. He or she must "speak the speech" as Hamlet says, not "trippingly", but in a much more regimented and even shackled way. The actor is not free, as say Hamlet is in his famous soliloquy, to move entirely at his or her own pace, to create rhythm based on reading and interpretation of text. The composer has already done much of the work.

Thus in a staged melodrama one can either use musicians, most likely singers, or actors. If one uses singers, one gets inferior acting and vocal nuance. If one uses actors, there may be issues of timing, and a general insecurity about creating the kind of syncronization not expected in staged theatre, but obviously necessary in opera and stage melodrama.

Now, I am not suggesting that these challenges could not have been overcome, only that they were not. Historical reality is filled with far greater challenges that have somehow been met and solved. But I am certain that in order to do this there would have had to be an institutional shift that never took place (and one can hardly imagine singers allowing such a shift to get off the ground). In other words, there needed to have been an institu- 
tion devoted to presenting stage melodrama, where, from the top down, from high level performance to the very novice levels of training, focus was placed on solving the kinds of problems I have outlined. Schools filled with young melodrama actors, coming of age with orchestras particularly skilled at the tricks of the genre, leading to an environment simultaneousy competitive and supportive, might well have allowed the genre to realize its potential.

We do not often acknowledge the extent to which institutions shape performance realities, but it is a critical factor. The fact that we hear far more professional performances of Haydn symphonies than of his masses does not result from the fact that audiences have a decided preference for one over the other, but rather that we have an institution such as the "symphony orchestra association" set up for the purpose of playing symphonies, and no institution ideally set up to present masses. To present a mass one combines orchestra and chorus, and while all major orchestras, say in the United States, have associated choirs, they are usually not professional, and thus performing a mass requires coordination outside of the norm. This radically determines what works are performed and how often. Obviously, melodrama is such a special case in terms of institution, and long-term institutions to ensure its health have simply not been evolved and successfully sustained.

\section{III.}

But there is another, more fundamental reason that stage melodrama has been difficult to sell to audiences, and this involves questions of perception. I will try to introduce these ideas by relating something that took place not long ago, and it is something that has nothing to do with music or melodrama. I was in Lancaster, England at a conference and one of the speakers, giving a talk on Devetsil, stated that rather than showing specific images to illustrate points in his talk, he would simply "loop" the visuals which would cycle throughout his talk on a screen directly next to him. In this way, he hoped to avoid a certain kind of scholarly authority in favor of something more ephemeral. As a concept it was not bad, and perhaps even in sync with the more surreal tendencies of Devetsil. However, in practice, it created genuine difficulties, at least for me. Each time I turned, both physically and metaphorically, from the speaker and the speaker's points to the Devetsil images, I lost the thread of the discussion. I found myself quite unable to study an image while listening to text that actually had nothing to do with that particular image. It was not because I was jet lagged, or there was something wrong with the images or the talk. I had run up against my own brain and the way it makes sense of things.

This same thing happens when we combine music and text. Try it yourself if you have not already done so. Read any text with music playing in the background and try to follow it, as if preparing to answer questions. Although some musicians claim that they absolutely cannot read with music playing, point a gun at their heads and threaten them if they fail to answer questions about the text, and I guarantee you that the music will be "backgrounded" soon enough. But the opposite poses insoluble problems for almost all listeners. For when you ask people, say, to follow the oboe line in the $2^{\text {nd }}$ Brandenburg 
Concerto and try to read something at the same time, they cannot do it. And in attempting to do so, they become temporarily aphasic, that is, unable to read even a single phrase while "following" a musical argument.

The problems this might present for stage melodrama are obvious. Forcing the audience to continually go back and forth between types of listening is enervating. What we need to process music and what we need to process text are dissimilar. Thus what we call "song" actually involves an intermediate stage where, while we are aware of text, we do not attend to it in the same way we listen to spoken language. Perhaps all of us have had the experience of listening to particular songs over long periods of time, only to realize we have never understood the text. This is unthinkable with spoken language, where we either understand or we do not.

If this is the case then, and there is something "wrong" with stage melodrama in a cognitive sense, how is it that the genre could become so tumultuously successful in its film and television incarnations? I think the answers are quite clear. Film and television are not composers' genres, they belong more than anything to writers, directors and actors. Although there are many ways to put a film together, one rarely, if ever, begins the process with music. In fact, once the medium in its own theatrical flexibility has been realized, the composer comes in like some kind of colorist, often creating stunning effects to be sure, but responding to a conception already in place. This means that actors can be actors, moving with flexibility and naturalness, not in any way forced to conform to the rhythmic mandate of the music that seems to surround them.

Though music has not relinquished its power in film, it almost never competes with the stage action, nor can it, without risking the destruction of the whole. It is like acting itself: just as great actors do not call attention to themselves as actors, it is almost unheard of for great film music to call attention to itself while the actors are on screen.

Keep in mind that throughout this discussion I have spoken of staged melodrama. I do not think the same issues hold for concert melodrama, though some of them might. There are several reasons for this. Since concert melodrama involves a single speaker, or narrator, there is far less in terms of divided attention compared with stage melodrama, and since many of the concert melodramas are based on well-known stories, or are short in terms of length, there is no real question of strain in terms of following the basic thrust of the whole. Also, with a single speaker, there is usually time to work out a genuinely nuanced performance.

IV.

I hope that my ideas to this point do not suggest that I have no passion for melodrama, nor that I have simply parroted the notion that it is somehow a failed form. Quite the contrary, I am always intriguied by the untapped potential of the genre. But it does seem to me that unless performances of staged melodrama are simply to be museum pieces, where works from the $18^{\text {th }}$ through $20^{\text {th }}$ centuries are set in stone, a serious updating must take place based on an understanding of how we perceive things and why. 
Thus any performance of staged melodrama should be experimental, and should keenly attune itself to the creation of the kinds of powerful effects that can only be created with melodrama. The great stage melodramas of Fibich need to be translated in several ways. First, there need to be serviceable translations into different languages in such a way that, while not losing any of the intent of the original, the performance aspects of the text are always kept in mind. But another kind of translation is also required. Those seeking to revive stage melodrama must work together to evolve innovative performance styles that allow contemporary audiences both in and out of the Czech Republic to grasp the essence of the genre. If serious actors are to be used, ways must be found to make stage melodrama as much an actors' genre as a composers' and there must be ways of exploring how much nuance actors may be given in order to realize the very rationale for their existence in a composer-generated show. The natural process of going back and forth between modes of cognition must be acknowledged and treated as a problem to be solved.

Actually, far from invalidating and outdating stage melodrama as a genre, television and film may have whetted an appetite for it. And there is no reason why the coming decades cannot be a moment of astonishing revival where the finest actors and brilliant musicians, stage designers, lighting experts and audiences come together for the most exciting kinds of spectacle, the kind that excites precisely because Medea, as we noted, will never like Hamlet be carried to her resting place by flights of angels.

\section{Medea, Melodram und die Grenzen der Wahrnehmung}

\section{Zusammenfassung}

Das szenische Melodram stellt sowohl an seine Ausführenden als auch an sein Publikum außerordentliche und subtile Anforderungen. Nicht nur müssen die Interpreten lernen, ihre Worte auf eine vom traditionellen Theater völlig verschiedene Weise mit der Musik abzustimmen, sondern die Zuhörer wechseln auch ständig zwischen der Aufmerksamkeit auf musikalische Vorgänge und dem Erkennen und Erfassen traditioneller dramatischer narrativer, durch das gesprochene Wort strukturierter Texte. Diese Probleme haben es, besonders im Hinblick auf mögliche Störungen in der Auffassung von Zusammenhängen zwischen Wahrnehmung und Erkenntnis, für das szenische Melodram sehr schwer gemacht, neben vergleichbaren Genres wie Oper, Musical, Drama und Film erfolgreich zu bestehen. Trotzdem bewegt und erfreut das Melodram sein Publikum noch immer auf einzigartige Weise, und deshalb müssen diejenigen, die am Fortbestand und sogar an einer neuen Blüte des Melodrams interessiert sind, weiterhin an der Schaffung einer „melodramatischen Infrastruktur“ arbeiten.

Übersetzt von Vlasta Reittererová 


\title{
Médea, melodram a limity percepce
}

\begin{abstract}
Shrnutí
Scénický melodram klade jak na interprety, tak na publikum mimořádné a komplikované nároky. Nejen herci se musí naučit synchronizovat své promluvy s hudbou naprosto jiným způsobem, než vyžaduje tradiční divadlo, ale také publikum neustále přesouvá pozornost od hudby ke sledování vyprávěcího rámce hry. Tyto problémy, zejména s ohledem na disjunkci v kognitivním myšlení a percepčních možnostech, znesnadňují scénickému melodramu, aby působil s takovým účinkem jako např. opera, muzikál, drama a film. Přesto melodrama působí na publikum svou unikátností, a proto ti, kteří udržují tradici melodramu nebo se dokonce starají o jeho vzestup, musí pečovat o „melodramatickou infrastrukturu“.
\end{abstract}

\section{Keywords}

Melodrama; cognitive limitations. 